\title{
O olhar estético do afeto: reterritorializando o Rio de Janeiro
}

The aesthetic look of affect: reterritorializing Rio de Janeiro

Lia Beatriz Teixeira Torraca [I]

\section{Resumo}

Este artigo busca apresentar o olhar estético do afeto como possibilidade para sensibilizar e reprogramar a percepção social no Rio de Janeiro a partir do olhar da Favela. Uma técnica para "fazer ver", "transformar o ver em olhar" e "fazer agir sobre" através da experiência fotográfica. Uma alternativa para reimaginar a cidade sob outra perspectiva e poder reconfigurar a imagem do Rio de Janeiro e suas relações a partir da virtualização e projeção das imagens fotográficas produzidas na favela, ou seja, um recurso para reterritorializar a cidade. Uma proposta construída a partir do conceito de desterritorialização de Pierre Lévy e na teoria de imagem complexa de Josep Català Domènech, tendo como referência metodológica a Fenomenologia da percepção, de Maurice Merleau-Ponty.

Palavras-chave: reterritorialização; estética; fotografia; percepção; afeto.

\begin{abstract}
This article seeks to present the aesthetic look of affection as a possibility to sensitize and reprogram social perception in Rio de Janeiro based on the perspective of the Shantytown. This is a technique to "make you see", to "transform looking into seeing" and to "make you act on" through the photographic experience - an alternative to reimagine the city from another perspective and to be able to reconfigure the image of Rio de Janeiro and its relations through the virtualization and projection of photographic images produced in the Shantytown, that is, a resource to reterritorialize the city. This proposal was built on the concept of deterritorialization proposed by Pierre Lévy and on Josep Català Domènech's complex image theory, having the "Phenomenology of Perception" by Maurice Merleau-Ponty as the methodological reference.
\end{abstract}

Keywords: reterritorialization; aesthetics; photography; perception; affection. 


\section{Introdução}

Neste trabalho de pesquisa, buscamos pensar o Rio de Janeiro sob outra perspectiva, uma cidade reimaginada através do olhar da favela. Uma possibilidade de reprogramação perceptiva e de sensibilização, a partir dos estudos sobre imagem, estética e virtual, que permitiria pensar uma cidade "pós-neoliberal", uma cidade reterritorializada. 0 olhar estético do afeto poderia promover a reconfiguração da imagem da cidade e suas relações através da experiência estética. Uma pesquisa que tem na Fenomenologia da percepção, de Maurice Merleau-Ponty, sua referência metodológica, principalmente em razão de a fenomenologia constituir um método de apreensão da realidade comprometido com a experiência e com a crítica, além de precioso instrumento cognitivo, conforme destacam Lopes e Pimentel (2011, p. 93). A fenomenologia merleaupontyana é um convite àquilo que é essencial na percepção: "abrir-se a um outro e sair de si" (Merleau-Ponty, 1999, p. 571); possibilitando a observação da construção da realidade e da descrição da experiência perceptiva, aquela que permite ir além da empatia, inaugurando um processo de identificação que promove simpatizar com o outro, conforme sugere Cortina (2017). Essas mudanças perceptivas se refletem no entorno e implicam o comprometimento com o outro a partir da reformulação do padrão comunicativo.

Este trabalho de pesquisa está dividido em três etapas, iniciando com a apresentação do olhar estético do afeto, para, então, desenvolver o conceito de reterritorialização e o que seria o processo de reterritorialização por intermédio da experiência estética. Vale ressaltar que o olhar estético do afeto foi desenvolvido durante a pesquisa de doutorado pelo Programa de Pós-Graduação em Direito da Universidade Federal do Rio de Janeiro, buscando oferecer uma alternativa ao enfrentamento da violência no Rio de Janeiro. Uma técnica construída a partir da hipótese de que a cidade está estruturada sob uma dinâmica circular de violência, conforme Watzlawick (1991, p. 93) descreve, o padrão de interdependência, sendo possível rompê-la por intermédio da estética; ou seja, a partir da alteração da percepção seria possível modificar a modulagem dessa comunicação e romper a circularidade da violência que marca as relações em uma cidade dividida entre espaços de inclusão e outros marginalizados. Uma estética de segregação que reflete a própria circularidade de violência, entre o racismo escamoteado, a aporofobia despercebida e outras formas de violência que restam normalizadas. A ordem é fixada sob uma dinâmica comunicativa de ameaça constante e recíproca, uma percepção amplificada pelos meios de comunicação que acabam por promover a legitimação de medidas de contenção e controle que retroalimentam e potencializam a circularidade de violência no Rio de Janeiro. Uma dinâmica social que adotou a forma de espetáculo, tal como Debord (1997) descreveu a sociedade contemporânea, responsável por configurar a imagem de uma cidade maravilhosa em retrato da violência. Uma forma de comunicação que percebe o outro - diferente - como um inimigo a ser abatido, legitimando medidas violentas que provocam o recrudescimento da violência. Até mesmo a paz se apresenta como face da violência da cidade ao vincular a percepção de segurança à imagem de uma polícia 
que empunha símbolos violentos, o que acaba por estimular a substituição da imagem da justiça por uma ideia de justiçamento.

0 olhar estético do afeto pretende não só fazer visíveis as formas dessa violência no Rio de Janeiro, mas alterar a percepção sobre a favela como retrato da violência a partir de imagens produzidas pela própria favela. Não é a favela que precisa se transformar, mas o olhar que insiste em vê-la como locus de violência é que precisa ser modificado.

Acredita-se que essa alteração de percepção se faz possível a partir de outra perspectiva, capaz de projetar outra imagem da Favela e da cidade. Uma técnica fundada na experiência perceptiva despertada pelo afeto, que permitiria deslocar o foco da questão da violência no Rio de Janeiro para imprimir outra forma de ver a violência e, portanto, outro padrão de comunicação ancorado na concepção spinoziana sobre afeto. A fotografia seria o medium para construir outro retrato da favela, não aquela imagem associada a ameaça, medo e estigmas, mas para ser olhada como espaço de experiências afetivas e transformadoras. Uma nova forma de pensar a cidade através da desterritorialização das imagens produzidas na favela, conforme o conceito construído por Pierre Lévy, no qual as imagens virtualizadas no ciberespaço seriam projetadas por intermédio de experiências estéticas, tal como Català Domènech reflete sobre uma imagem complexa.

Este seria o processo de reterritorialização do Rio de Janeiro. Uma proposta para reimaginar o Rio de Janeiro e suas relações a partir da virtualização e da projeção da experiência fotográfica, não se tratando de uma cidade digital, mas da reconfiguração perceptiva a partir do olhar do sujeito oprimido, diversa daquela imagem que foi responsável por modular as relações de uma cidade sob o olhar do opressor.

Figura 1 - O som complexo da favela

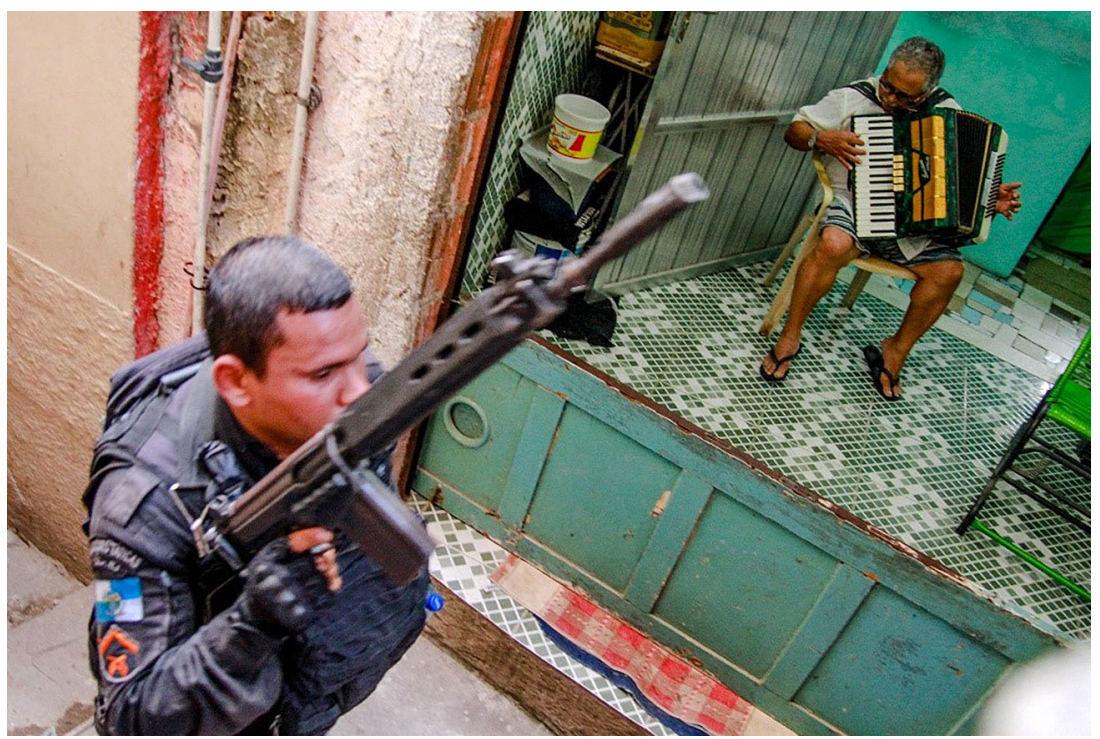

Fonte: foto de Bruno Itan. 


\section{O olhar estético do afeto}

O olhar estético do afeto oferece a possibilidade da ampliação da percepção, da emancipação do ver para transformá-lo em olhar. É a oportunidade de reconstrução do padrão comunicativo traduzido como violência. Um olhar que permite a radicalização da síntese perceptiva, ou seja, outra forma de perceber, afetar e fazer agir. É, a partir da experiência fotográfica, através das lentes do afeto, que se estabeleceriam a elaboração do conteúdo percebido e a produção de um novo real. Um processo de "afetar e afetar-se" através da relação com o mundo percebido, a partir de outra perspectiva, que, nesta proposta, é a favela. A fotografia, como nos lembra Azoulay (2008, p. 129), age fazendo com que os outros atuem, além de operar como mediadora na relação entre sujeito e metrópole, localizando o "eu" no espaço urbano, ainda que seja cada vez mais evidente que o regime de visualidade da própria metrópole é responsável por calibrar a sensorialidade do sujeito, como observa Costa (2010, p. 50).

0 olhar estético do afeto permite a produção do olhar. Ver, perceber e olhar são fenômenos distintos e não estão relacionados à visão. Segundo Català Domènech (2011, p. 19), a visão faz parte de todo o corpo, como sua propriedade, daí ser comum afirmar que vemos por meio do corpo, pois nosso campo visual se dá a partir da localização corporal, fazendo com que a experiência visual seja considerada uma experiência corporal. O visual é, portanto, um fenômeno complexo inscrito na visualidade; ver "é pensar a realidade, em um grau ou outro de intensidade" (ibid., p. 52). Mas é preciso atentar que nossas emoções são fruto de uma cultura visual que pode modular e calibrar nossa percepção. A sociedade impõe filtros particulares sobre aquilo que vemos, controlando, limitando, restringindo a capacidade da nossa visão; o olhar estético do afeto pretende desbloquear a experiência perceptiva por intermédio de outro filtro: o afeto. Uma experiência visual que, aliada à experiência afetiva, é capaz de executar a transição da contemplação à ação, tal como pensada por Arendt em seu livro A condição humana (2007), e que Didi-Huberman (2016) defende estar relacionada às emoções, apesar de questionar sua relação com as imagens, da exposição e da imposição social em um regime que domestica nosso sentir para atender a uma forma de aparência. A transformação da visão passiva em visão ativa do olhar é a síntese da experiência perceptiva, é a imagem complexa descrita por Català Domènech, considerada como nossa visão consciente, capaz de interrogar e fundamentar uma reflexão complexa do mundo (p. 54). Essa capacidade se traduz na força do nosso agir. O olhar pode transformar o ambiente a partir da percepção, preconizando a visualização. É a imagem que nos faz compreender a realidade e não a visão, explica o autor, pois visualizar "é colocar o fenômeno em imagens por intermédio de diversos recursos visuais" (ibid., p. 59).

A relação entre olhar e fotografar diz respeito "ao certo uso do olhar" preconizado por Merleau-Ponty. O olhar, segundo Català Domènech (2011, p. 53), é "ver o limite de nossa visão, significa ver a imagem inclusive na própria realidade: ver a realidade como imagem"; é, portanto, ver o ilimitado do real na imagem. A fotografia surge como o medium desse olhar, dessa forma de perceber e conceber imagens. Imagens que sejam capazes de afetar e fazer agir, que transcendam 
a representação e possam romper um padrão comunicativo. São imagens que sensibilizam e promovem o comprometimento com o outro, com o outro espaço. É do seu aspecto paradoxal que surge a possibilidade da desterritorialização, pensada por Lévy (2007); afinal, como pontuou Barthes, a fotografia separa a atenção da percepção, libertando a atenção e a produção de sentido pelo receptor em relação à imagem fotografada. Esta é a energia das imagens fotográficas, que Sontag diagnosticou ter origem na própria realidade da fotografia (2004, posições 2412 a 2414), levando-a a defender a complementaridade entre as noções de imagem e de realidade (ibid., posição 2139). É, nessa potência, que reside a possibilidade da reterritorialização através da imagem.

A fotografia, além de ser um meio de ver a realidade sob determinada perspectiva (fotografar), é uma forma de comunicação através da imagem fotografada com o espectador do registro fotográfico, portando a capacidade de ir além do visto ao autorizar a produção do olhar, ou seja, a síntese da percepção, de acordo com a concepção merleaupontyana. Essa síntese diz respeito ao ver e o ver-se, de acordo com Martins (2017), radicalmente inscritos na realidade das relações sociais, fundamentais à sociologia, ainda que não tenham como material a realidade. Fotografar é um modo de construir a realidade de modular a percepção. 0 ver fotográfico seria uma espécie de decodificação da realidade, de acordo com Sontag, uma expressão da experiência do real e da busca de sentido em face do espelho, "o único modo de fazer a fotografia atravessar o espelho" (Martins, 2017, p. 55). Esta seria a capacidade da fotografia em adestrar a "visão intensiva", segundo o visionário Moholy-Nagy (1995).
De acordo com Benjamin (2013; 2017) e Barthes (2015), o punctum seria responsável pela capacidade de afetar por intermédio da fotografia. 0 punctum é o afeto que faz possível a abertura do espaço e do tempo. É aquilo que, na imagem, me afeta, me punge, desperta meu olhar e pode me transformar porque provoca meu agir. $\mathrm{O}$ olhar como síntese da experiência perceptiva, descrita por Merleau-Ponty (1999), dá-se como em um mergulho dentro da imagem da fotografia através do meu olhar sob o olhar do outro, para, assim, voltar-me para mim - que percebo. O punctum pode organizar não só nosso olhar, mas reunir vários olhares sobre uma mesma realidade, ampliando o campo de visão e, dessa maneira, atingir além do percebido, confirmando a experiência fotográfica como uma oportunidade que todos ganham em ver através do olhar do outro, ressalta Azoulay (2008, p. 107). A experiência fotográfica é uma projeção do meu mundo. A partir dessa projeção, é construído um novo mundo, uma nova realidade. Um mundo que, segundo Lévy, é o próprio sujeito, "com a condição de estender-se por este termo tudo o que o afeto envolve"; o sujeito, portanto, "é um mundo banhado de sentido e de emoção" (2007, p. 107). Localizado no virtual, é um sujeito afetivo que "desdobra para fora do espaço físico" (ibid.), um sujeito desterritorializado e que pode ter alterada sua percepção. Ao retornar como projeção, o sujeito reterritorializa-se a partir da experiência estética, alterando novamente sua percepção sobre si mesmo e sobre o entorno, o mesmo ocorrendo com as imagens, em especial as imagens da cidade, capazes de reterritorializar o espaço urbano e suas relações, ou seja, reconfigurar a percepção social. Os afetos, segundo Lévy, seriam responsáveis por atualizar o virtual (ibid., p. 108). 
Essa atualização provocaria a eclosão de novos tipos de afetos, o que poderia ser considerado uma inventividade afetiva, sendo este "o imenso jogo afetivo que produz a vida social" (ibid.). É essa inventividade afetiva que autorizaria processar a reterritorialização.

O olhar estético do afeto expõe essa prerrogativa da imagem para despertar algum tipo de emoção no espectador para que seja possível processar a síntese perceptiva, ou seja, transformar o ver em olhar. Essa transformação é a essência da experiência estética, dado que a estética é "uma forma de qualificar uma propriedade emocional intrínseca de toda função visual" (Català Domènech, 2011, p. 28). Esta é a função emocional das imagens identificadas por Català Domènech. É a potência do visível em afetar o receptor da imagem, "diante do que vemos e, mais ainda, se o vemos representado" (ibid.). Porém, também podemos acessar o invisível na imagem, adverte Merleau-Ponty, o que seria efeito do punctum despertado na experiência fotográfica e, portanto, da chave do sensível. Para Català Domènech, a representação visual seria um meio de controlar nossas emoções diante do visível, principalmente porque as imagens emocionais, aquelas que colocam o fator emocional em primeiro plano, fazem possível experimentar o real por intermédio de uma emoção. Apesar da crença de que a imagem fotográfica seja eminentemente técnica e, assim, elimine qualquer vestígio de subjetividade na captação do real, ou de emoção, o autor do conceito de imagen compleja (Català Domènech, 2005) aponta a preponderância do desejo - do afeto - nessa relação com a imagem, e não a realidade em si; afinal, segundo Català Domènech, a própria ausência de emoção é uma emoção que também se experimenta emocionalmente (ibid., p. 30). Para Didi-Huberman (2016), a emoção refere-se ao movimento, "uma e-moção, quer dizer, uma moção, um movimento que consiste em nos pôr para fora (e-, ex) de nós mesmos" (p. 26). É a possibilidade de sair do estado contemplativo para agir, como Arendt (2007) pensava a transição do estado passivo para o ativo. É a partir do conhecimento sensível que se processa a transformação ativa do nosso mundo, tal como preconizada por Merleau-Ponty, um momento afetivo que torna possível a mudança do sujeito ao interagir com outros mundos. É a "pregnância de emoção" que porta a imagem sintoma pensada por Charaudeau (2006), aquela "imagem já vista, que remete a outras imagens, seja por analogia formal, seja por intermédio de discurso verbal" (p. 245). Uma imagem convergente àquela imaginada por Didi-Huberman, estruturada a partir da imagem dialética benjaminiana e sua construção de uma dialética do ver, próxima da experiência perceptiva merleaupontyana, entre corpo e imaginação, que, em certa medida, reflete a concepção spinoziana, qual seja, sermos afetados pelo vivido cristalizado como imagem reverberada semanticamente.

A fotografia de uma cidade dividida pode abrir uma visualidade, acredita Martins (2007). Uma visualidade que se oferece como desafio ao fotógrafo por constituir a imagem da realidade social. Porém, são imagens que precisam de informações para que sejam compreendidas, pois elas não são autorreferentes, destaca Martins ao se referir à "polissemia da fotografia" para explicar o poder das imagens fotográficas. Essa potência não só permite múltiplas leituras, mas carrega "uma carga de sobressignificados que a intenção documental do fotógrafo pode anular ou mutilar" (ibid., 
p. 169), fazendo parte da própria produção de realidade e da sua função de decifrar ou decodificar a desordem e os desencontros do espaço urbano, parte integrante do campo da visualidade da fotografia. Para o sociólogo, o importante na fotografia residiria no imaginário social de que ela é meio, na imaginação mediadora que suscita. Nessa perspectiva, Martins identifica uma tensão entre o punctum, "como ponto de impacto visual, e a coadjuvação dos componentes complementares da imagem, residuais e imprecisos, que se pode fazer a leitura não só da imagem, mas do imaginado que a situa e a define" (ibid., p. 173). Esse impacto do punctum, se considerado como aspecto fragmentado e descontextualizado, de acordo com Català Domènech (2005, 2011), faria parte do fenômeno da espetacularização da sociedade, o que explicaria nossa atração - pelo punctum - por imagens descontextualizadas que acabam esvaziadas, perdendo potência, sentido e a capacidade de afetação e contágio.

Ao questionar se nossas emoções básicas estariam ligadas ao visual muito mais diretamente do que se poderia pensar, implicando a hipótese da emoção estética exceder o conteúdo de toda a nossa arquitetura emocional, Català Domènech (2011, p. 28) acaba encontrando em suas investigações a potência da imagem emocional, do seu poder de modificar a percepção a partir da emoção que desperta, expressa na concepção spinoziana sobre a potência do afeto. De acordo com o autor, as imagens tanto guardam uma condição autônoma, relacionada ao conceito de sintoma e, portanto, ligada às visualizações, conforme Charaudeau (2006) entende a imagem sintoma; como carregam uma carga expressiva, capaz de transformar-se em visão emocional e despertar o olhar do espectador a partir da emoção que cada imagem porta. Essa emoção é capaz de deslocar o olhar e provocar o desfocar-se do indivíduo. Esse processo de transferência de foco implica a alteração das prioridades desse indivíduo e no compartilhamento do olhar, justamente porque "o mundo se pulveriza em qualidades sensíveis" (Merleau-Ponty, 1999, p. 305), porque esse outro olhar provoca o despertar de um outro olhar sobre o real, e todo esse processo é impresso no corpo, uma percepção sentida corporalmente em um transbordamento de registros sensoriais, conforme observou Merleau-Ponty. Ver o outro e o outro espaço por intermédio da fotografia e se deixar afetar por essa imagem do outro e do outro espaço, permitindo-se a produção de outros olhares sobre a imagem, construindo outra imagem, isto é, o olhar estético do afeto. É a possibilidade de reprogramação do padrão comunicativo a partir da experiência estética que promove a produção de outras imagens, substituindo nossas lentes e educando nosso ver. Esta é a potência da reterritorialização.

\section{Reterritorializar: uma nova estética urbana}

O conceito de virtual formulado por Lévy (Lévy, 2007) nos permite pensar o que seria a reterritorialização a partir de uma nova sensibilidade estética. Para o autor, a virtualização implicaria a desterritorialização do corpo, seja do sujeito, seja do objeto, abrindo a possibilidade de erigir quadros coletivos da sensibilidade. Vale lembrar que Deleuze e Guattari também pensaram a desterritorialização; ${ }^{1}$ entretanto, Lévy 
localiza o conceito no virtual, essencial para a proposta de reterritorialização. Um conceito associado à percepção.

Antes de prosseguirmos, faz-se necessário destacar alguns aspectos sobre a experiência estética. 0 primeiro aspecto foi Aristóteles (2018) quem apontou, ao inaugurar os estudos sobre estética, relacionando esse conceito à percepção e ao afeto. Aristóteles observou que, no ato de perceber, o sujeito é afetado pelo objeto percebido, composto de forma e matéria, chegando, inclusive, a afetar o próprio corpo daquele que percebe. Estética, portanto, refere-se àquele que nota, percebe, afeta e é afetado. A estética é a teoria do conhecimento sensível (estesiologia), do despertar, "a estética é uma forma de qualificar uma propriedade emocional intrínseca de toda função visual" (Català Domènech, 2011, p. 28), confirmando que nos afetamos em diversas possibilidades de graduação, sendo a representação visual "uma forma de controlar nossas emoções diante do visível" (ibid.). Merleau-Ponty (1999, p. 45) deposita no sensível a origem da percepção, considerada como o trânsito da significação. É no perímetro ampliado do campo visual que estão localizados os reflexos de superfícies sensíveis que tornam possível o olhar, a síntese da percepção. 0 olhar estético do afeto revelaria ao que, para Rancière (2018, pp. 13; 15-18; $26 ; 28 ; 32-44 ; 63-65)$, é a política estética através da distribuição do sensível.

Outro aspecto importante na experiência perceptiva é a imprescindibilidade do outro, pois a percepção só passa a existir quando alguém a percebe, pois o visto não pode ser reduzido apenas à experiência individual. É a ampliação do meu campo de visão a partir do outro, de como o outro vê, pois é, por intermédio da percepção de outrem, que eu posso me encontrar posto em relação com um outro eu; uma percepção realizada a partir de outra subjetividade, aponta Merleau-Ponty, que, no caso da desterritorialização, é a subjetividade do sujeito oprimido. É o canal perceptivo que nos permite afetar e sermos afetados, sendo possível estabelecer novos padrões comunicativos e provocar nossa imaginação. 0 mundo da concepção merleaupontyana não é aquilo que eu penso, mas aquilo que eu vivo; é minha experiência que exprime aquilo que eu entendo de mundo. A percepção é a porta para questionar e refletir sobre a própria estrutura daquilo que é visto pelo sujeito para que, assim, possa reconstruir o seu olhar e, consequentemente, o seu ambiente.

0 último aspecto que merece destaque antes de prosseguirmos é sobre a fotografia na concepção merleaupontyana, apontada como um meio para descrever a experiência perceptiva. Com base nessa experiência, estabelece-se o que Merleau-Ponty entende como "comunicação verdadeira", aquela fundada nos elementos da descrição do mundo percebido, da síntese de um mundo fotografado. A partir dessa forma de descrição, seria possível modificar a percepção sobre uma imagem comunicada como realidade e produzir outra realidade mediada pelo afeto. Uma percepção que é fruto de determinada experiência; este é o pensamento de perceber, defende Merleau-Ponty. Para Tomkins (1962, p. 13), precursor da Teoria do Afeto, o que é percebido conscientemente é imageria, criada pelo próprio organismo. 0 mundo percebido é, segundo ele, aquele apreendido a partir de um roteiro não escrito pelo sujeito que percebe. Todo o querer e não querer do sujeito, positivo ou negativo, seu relatório de propósitos, ou seja, sua imagem, de acordo com Tomkins, 
são principalmente experiências estéticas, repercutindo no seu comportamento e no ambiente. Massumi, outra referência nos estudos sobre afeto, desenvolveu sua teoria a partir da distinção entre o factual e o emocional, considerando a primazia do afetivo na recepção da imagem, marcada pela lacuna entre conteúdo e efeito, ou melhor, sobre a conexão entre efeito da imagem e seu conteúdo. Para Massumi, o afeto seria a dupla face da "participação simultânea do virtual no real e o real no virtual, à medida que se origina e retorna ao outro" (Massumi, s/d., p. 14). Afetos, segundo ele, são "perspectivas sinestésicas virtuais ancoradas em (funcionalmente limitadas por) coisas particulares existentes que as incorporam" (ibid.). Essa concepção de afeto nos ajuda a refletir sobre a interação contemporânea na relação homem e tecnologia, corpo e máquina, entre toque, dispositivo e imagem. Para Massumi, a autonomia do afeto é sua participação no virtual, sua autonomia é sua estrutura, sendo a autonomia da emoção a autonomia do afeto.

O conceito de virtual não é novo, mas ganha nova perspectiva quando é pensado como "um processo de transformação de um modo de ser num outro" (Lévy, 2007, p. 12), ou seja, quando é refletido sobre o trânsito do real ou do atual em direção ao virtual, que consiste no conceito de desterritorialização aludido por Lévy.

Nossa proposta é pensar o processo inverso, esse novo virtual projetado no real, implicando uma reconfiguração perceptiva a partir da experiência fotográfica. Uma experiência refletida a partir da pesquisa empírica junto ao Projeto "Olhar Complexo", criado pelo fotógrafo Bruno Itan, morador do Complexo do Alemão, como também a observação sobre sua obra fotográfica.
Um projeto fundado em 2017 com o objetivo de mudar o olhar sobre a favela, de acordo com a explicação do próprio Bruno Itan, pretendendo transformar o olhar negativo em positivo, como também construir uma memória da favela, partindo da mudança do olhar do próprio morador do Complexo do Alemão (Torraca, 2019, p. 206). O Projeto Olhar Complexo significa, para a maioria das alunas e dos alunos, a oportunidade de mudança, inclusive em relação à questão da violência, conforme resta explícito na fala de uma aluna: "este trabaIho pode mudar muito, muito, essa violência" (ibid., pp. 251-252). Tanto o trabalho individual de Bruno Itan quanto seu Projeto Olhar Complexo carregam a potência de deflagrar uma revolução através do olhar. Bruno Itan conseguiu encontrar uma estratégia para construir outro olhar sobre a favela a partir da própria favela, um espaço comunicado como território de risco, associado à criminalidade e que alguns pretendem riscar do mapa. ${ }^{2} \mathrm{O}$ olhar complexo de Bruno Itan é o olhar sobre si mesmo e sobre o outro, um olhar que torna possível a reconfiguração da percepção do próprio morador da favela sobre sua imagem e aquilo que vê refletido no lugar onde vive, onde construiu seus laços de afeto e sua identidade. Esse outro olhar pode fazer a diferença no enfrentamento da violência no Rio de Janeiro, conforme exposto na fala das alunas e dos alunos do Projeto Olhar Complexo. Uma experiência que vai além da favela, para promover outra percepção sobre ela, não mais como imagem associada à violência, mas para ser olhada por outra perspectiva.

A experiência estética promovida por intermédio do olhar estético do afeto e a possibilidade de reterritorialização do Rio de Janeiro convergem com a proposta do professor 
Figuras 2 e 3 - Projeto Olhar Complexo

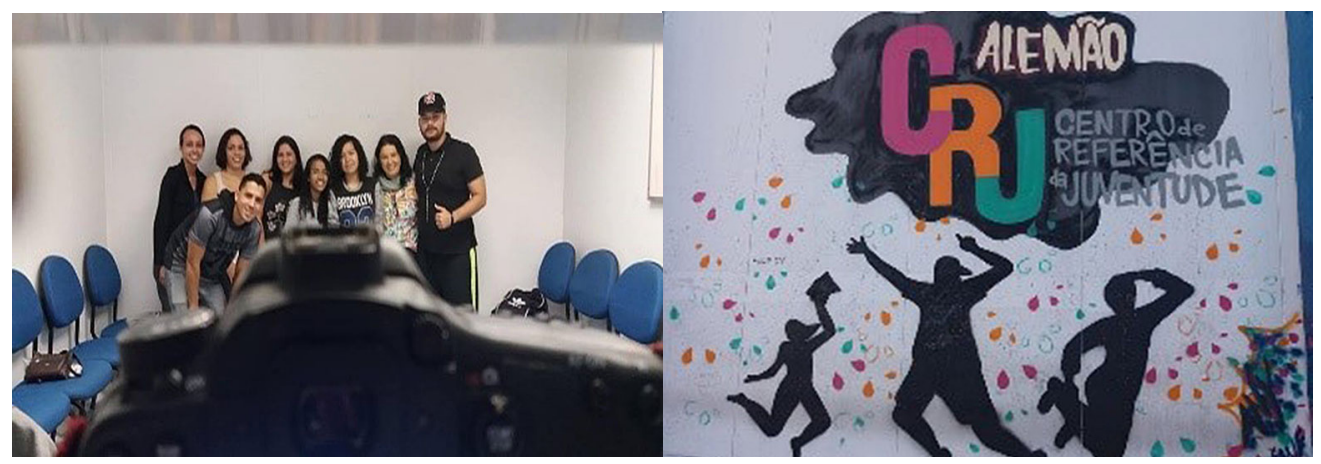

Fotos de Lia Beatriz Torraca.

Cristovão Fernandes Duarte de "reinvenção" da cidade a partir da favela, "entendida como o lugar do encontro e da troca entre os diferentes" (Duarte, 2019, p. 197), "construída como resposta aos processos de exclusão e segregação espacial" (ibid.), pois a "solução para as favelas" - e para a cidade -, segundo ele, "não está fora das favelas, mas no reconhecimento de que a favela [...] representa a 'reinvenção' da própria cidade" (ibid.). Uma "reinvenção" do Rio de Janeiro a partir de outro espaço-tempo, aquele impresso pelo ciberespaço, que institui outro sentido ao conceito de territorialidade, voltado para a percepção, tal como pensado por Deleuze e Guatarri sobre a possibilidade de desterritorialização, e que Pierre Lévy investe em sua investigação sobre virtualização, deslocando a perspectiva. Lévy (2007) destaca o fato de a percepção representar uma aproximação do mundo para aquele que percebe, defendendo que "a função simétrica da percepção é a projeção no mundo, tanto da ação como da imagem" (p. 28), sendo os sistemas de realidade virtual capazes de transmitir mais do que imagens, por permitirem a possibilidade de "quase reviver a experiência sensorial completa de outra pessoa" (ibid.), ou seja, uma experiência de quase presença que pode ser intensificada através da experiência estética.

A projeção das imagens virtualizadas produzidas pelos moradores das favelas do Rio de Janeiro é uma potência em si e oferece a possibilidade de abertura da relação espaço-tempo, tal como refletido por Merleau-Ponty em sua Fenomenologia da Percepção, e defendido por Lévy ao conceituar virtual, virtualização e desterritorialização. Para esse autor, a diferença entre real e virtual transitaria na percepção do tempo, o real no presente e o virtual na projeção do tempo futuro (Lévy, 2007, p. 15). Ele defende que o oposto do virtual não é o real, mas o atual (ibid., p. 16), como um devir que alimenta de volta o virtual (ibid., p. 17), em uma permanente reconstrução (ibid., p. 42). Para Lévy, a virtualização 
como dinâmica pode ser definida como movimento inverso da atualização, consistindo na passagem do atual ao virtual, em uma espécie de problematização, provocando o contínuo repensar de um problema e outra capacidade de existência (ibid., pp. 20 ss), consubstanciada na desterritorialização (ibid., p. 21), quando se torna "não presente". O corpo, segundo Lévy, multiplicar-se-ia no processo de virtualização, implicando a mudança de identidade, em uma espécie de passagem de uma solução particular a uma problemática geral. A virtualização permitiria a abertura de novos espaços e novas velocidades, ao liberar o que era apenas aqui e agora, explica o autor (p. 68), o que estabeleceria uma complexidade de linguagem muito próxima da imagem complexa descrita por Català Domènech (2005 e 2011), referente às emoções complexas (Lévy, 2007, p. 68). Lévy define a virtualização como "o momento inverso da atualização" (ibid., p. 17), que ele entende como "invenção de uma solução exigida por um complexo problemático" (ibid.), impondo uma mudança do virtual "como maneira de ser, mas a virtualização como dinâmica" (ibid.,), o que implicaria uma "mutação de identidade, um deslocamento do centro de gravidade ontológico do objeto considerado" (ibid., pp. 17-18), como também da alteração da percepção sobre a presença em razão da interferência no espaço-tempo que a virtualização provoca (ibid., pp. 18 ss).

0 olhar estético do afeto seria uma forma de reterritorialização do discurso a partir de uma imagem que se desterritorializa ao ser virtualizada, o que é a essência da fotografia como ativismo para uma mudança social, descrita por Bogre (2012). Essa autora defende que uma questão pode deixar de ser abstrata quando é retratada. Esta também é a proposta de Azoulay (2008), com seu Contrato civil da fotografia, no qual busca refletir sobre o conceito de prática da cidadania através da imagem daqueles que ela aponta como "à beira da catástrofe" (ibid., pp. 195 ss). Um contrato no qual fotógrafo e fotografado fazem parte da mesma realidade, ou seja, "à beira da catástrofe". Um convite para repensar as divisões, os muros, os enclaves e as exclusões a partir das imagens dos territórios palestinos ocupados por Israel, permitindo estabelecer um paralelo com as favelas cariocas. É nesse sentido que Azoulay propõe desterritorializar o campo de visão (ibid., p. 277). Para a autora, fotografar é poder mediar as relações sociais e políticas entre os cidadãos, como também as relações entre os cidadãos e o poder (ibid., pp. 137-138).

A fotografia que retrata uma questão social porta a possibilidade de afetar individualmente e despertar a simpatia, ou seja, uma imagem pode impulsionar o trânsito da contemplação à ação, fazendo com que o espectador da fotografia se comprometa com a questão exposta pela imagem, refletindo-se na passagem da empatia à simpatia, que é uma forma de se reterritorializar, ou seja, o espectador experimenta outra perspectiva para olhar, sentir e agir. É o afeto que desperta a empatia e faz operar a simpatia. Quando você virtualiza essa imagem, você amplia as possibilidades dessa imagem, o que é da ordem da desterritorialização, conforme ressalta Lévy. Nesse sentido, a experiência do Projeto Olhar Complexo é a própria experiência preconizada por Benjamin (2017) de uma imagem dialética, voltada para aquilo que entendemos como tempo futuro, mas calcada em uma construção do tempo passado. É essa possibilidade de diálogo entre uma imagem já formulada e uma imagem complexa, conforme propõe Català 
Domènech. Um olhar sobre uma imagem capaz de afetar, provocar reflexões críticas e alterar percepções do vivido na possibilidade do porvir, de acordo com o entendimento de Lévy. Este também é o olhar estético do afeto, como possibilidade de construção de uma memória percebida e aquela que se estrutura na abertura do tempo. Essa questão está intensamente presente na experiência fotográfica tendo a fotografia como "coisa viva", que Barthes (2015) entende como a projeção da "confusão perversa entre dois conceitos: o Real e o Vivo" (p. 69), em uma espécie de abertura do tempo. A experiência do Projeto Olhar Complexo do fotógrafo Bruno Itan confirma a potência da qualidade sensível da fotografia. A forma de um olhar complexo que permite ver o outro e um outro espaço através da experiência fotográfica. Esse olhar permite focar por intermédio do despertar da qualidade sensível, do contágio do afeto. É, a partir do olhar, que eu transformo o ambiente, o mundo que me cerca, defende Ponty. É a possibilidade de abertura do tempo e do espaço, por intermédio da experiência estética e que pode transformar o olhar dos próprios moradores do Rio de Janeiro, a partir de um olhar produzido pela favela. Se a violência no Rio de Janeiro é a projeção de uma modulagem perceptiva que reflete uma cidade dividida e deposita, na favela, a imagem dessa violência, ao alterar a perspectiva, restaria permitida a interferência na percepção sobre o que é comunicado como violência, abrindo a possibilidade de projetar outras imagens, construir outras relações e outra memória social através de outro olhar sobre a favela a partir da própria favela.

São vários os momentos em que é possível observar a relação da imagem fotográfica com a abertura do tempo, como "um momento privilegiado, convertido em um objeto diminuto que as pessoas podem guardar e olhar outras vezes" (Sontag, 2004, posições 228-245). Uma relação com o tempo que, segundo Badiou (2018), é a possibilidade de encontrar a felicidade real, que supõe "uma liberação do tempo" (p. 35); apesar de a maioria das fotos não conservar sua carga emocional em razão do decurso temporal, pois, de acordo com Sontag, "os atributos e os intuitos específicos das fotos tendem a ser engolidos pelo páthos generalizado do tempo pretérito" (ibid., posições 294-295). Nesse sentido, o fotógrafo, segundo essa autora, refletiria essa ambiguidade na dimensão temporal da fotografia, entre um desejo em "catar antiguidades na realidade", nas "ruínas artificiais" (ibid., posição 1053), fazendo com que as próprias fotos sejam consideradas antiguidades instantâneas, confirmando a perecibilidade impressa pela contingência (ibid., posição 1093). Busca-se, por intermédio da fotografia, do ato de fotografar, a compreensão do mundo, até mesmo uma animação, aponta Barthes (2015, p. 25). A força de uma foto está na sua capacidade de manter desperta nossa percepção, além da possibilidade da abertura do tempo, ainda que não se deva descartar a influência do contexto no ato do ver.

A maneira como interagimos com o entorno por intermédio das imagens transforma nosso mundo perceptivo em uma espécie de metáfora, um modo complexo de traduzir nossa relação com o mundo, conforme Català Domènech (2011, p. 56) pensa a imagem do "nosso tempo", una imagen compleja. Foi Spinoza (2017, p. 111) quem primeiro buscou entender como o homem é afetado pela imagem e sua relação com o tempo, seu reflexo na abertura do tempo através da experiência 
perceptiva, inclusive sobre a existência da relação de proporcionalidade entre o número de coisas a que uma imagem está referida com o espaço que ela ocupa na mente. Spinoza buscou realizar a conexão das imagens das coisas às coisas que compreendemos clara e distintamente e à quantidade de imagens vinculadas à sua capacidade de ampliação para, assim, tornar vívidas as imagens das coisas (ibid., p. 223). Dessa proposição, é possível compreender o imaginar, na concepção spinoziana, como afirmação da existência do corpo, considerando o afeto como ponto de referência da relação observação versus tempo (ibid., p. 112). A reterritorialização é o processo relacionado à abertura do canal perceptivo por intermédio da abertura do tempo e do espaço, proporcionada pela experiência fotográfica. Uma experiência que permitiria a reterritorializar essas relações por meio do afeto e processar a identificação; abre-se, então, tanto o tempo quanto o espaço para que outra dimensão afetiva se estabeleça.

\section{Desterritorializar para reterritorializar}

O processo de desterritorialização para uma reterritorialização é a essência da experiência estética pensada por Berleant (2000); aquela que busca descrever a experiência perceptiva como uma potência daquilo que olhamos como estética, ou seja, uma investigação sobre a experiência estética e sobre situações nas quais o fenômeno estético acontece (ibid., p. 22). A experiência estética conceituada por Berleant reconhece-se intrínseca à percepção (ibid., p. 121), considerada como a mais inteira e completa experiência perceptiva (ibid., pp. 121-122). Para Lévy (2007), os sistemas de realidade virtual oferecem essa experiência, como também permitem "integração dinâmica de diferentes modalidades perceptivas" (p. 28) e a possibilidade da "quase presença". Uma experiência que subverte o extrativismo das imagens urbanas durante o processo de virtualização das imagens produzidas pela favela. A projeção dessas imagens por intermédio de diversas experiências estéticas, inclusive as de interatividade que englobam todo o processo perceptivo (Català Domènech, 2011, pp. 56 ss), como aquelas que utilizam dispositivos de realidade virtual, permite implementar o regime de reterritorialização, como uma espécie de reversão da virtualização imagética, mas que significa uma interferência na modulagem perceptiva, individual ou coletiva.

Para Català Domènech, Jay e Appadurai, entre outros autores, a realidade virtual está intrinsecamente relacionada ao aspecto globalizador das imagens contemporâneas. A realidade virtual, segundo Català Domènech (2011, p. 91), é o paradigma da fluidez digital por fazer coincidir a realidade com a imagem, responsável pela criação de uma imagem que fundamenta a experiência visual unitária. É a era das telas-mundo, dos museus digitais, da experiência visual programada, da interatividade. É a imagem da ilusão realista, da tentativa de reorganizar o que geralmente é exposto em museus e galerias convencionais que, segundo Rancière (2012), busca "suscitar o sentimento de distanciamento entre duas ordens - entre as aparências cotidianas e as leis de dominação - que reavivar uma nova sensibilidade diante dos signos e vestígios que testemunham uma história e um mundo comuns" (p. 77). 
Català Domènech (2011, p. 92) acredita que essas experiências comprovam a potência da imagem como resistência através da imersão mente-corpo na imagem, quando a imagem fluida perde o referencial e se transforma em um substituto da própria realidade à qual se sobrepõe. É a possibilidade de transformar o observador em ator, que passa da experiência visual à ação por intermédio do seu corpo (ibid., p. 92), como se fora uma tomada de consciência corporal conforme as sensações provocadas por aquilo que ele vê; afinal, aquilo "que o sujeito percebe se torna-se seu mundo da percepção, enquanto o que faz é seu mundo da ação" (ibid., p. 56).

Se Spinoza (2017, pp. 111-116) buscou demonstrar que o homem é afetado pela imagem, Català Domènech (2005, p. 268) transporta essa busca para o imaginado e o imaginário. Català Domènech propõe com a imagem complexa uma forma diversa de ver a imagem a partir da relação que o espectador tem ele, considerando a imagem fotográfica como uma imagem estática, aquela que é "plena, lotada: não tem vaga, a ela não se pode acrescentar nada" (Barthes, 2015, p. 77), da qual sua completude faz com que reflua da apresentação para a retenção (ibid.). Ele defende que a percepção complexa se caracteriza pela experiência convertida em uma potencialidade dela mesma, ou seja, "quando a imagem mental passa a ser representada em uma imagem e nós a observamos" (ibid., p. 92). Isto significa que a dicotomia entre espaços existencial e imaginário acaba se tornando uma força da articulação entre a percepção visual objetiva e a potencialidade imaginária de sua vivência, conforme explica o autor. Nesse sentido, é interessante pensar essas interações como performances em artes digitais ou museus digitais para promover experiências perceptivas mais intensas e dirigidas, o que também pode ser atingido através de intervenções imagéticas eletrônicas em configurações urbanísticas e arquitetônicas, como sugere Català Domènech (ibid., pp. 145-146), provocando uma espécie de mútua reinvenção da relação interno/externo. A imagem complexa, segundo esse autor, projeta o trânsito entre a realidade imaginada, considerada uma imagem comunicada, e uma imagem realizada, aquela que nos permite objetivar uma emoção (ibid., p. 166). Ele destaca a importância em distinguir os limites do olhar, estabelecendo as diferenças entre $o$ ato de ver e 0 ato de representar o visto, recomendando que se desmembre o ato de ver, além de pensar as imagens em relação aos mecanismos complexos, como os dispositivos essenciais de cognição, procedimentos simbólicos de cultura e psicológicos. Català Domènech acredita que se possa instituir uma "alfabetização visual" (ibid., p. 89), ou seja, uma forma de "enunciação da condição híbrida do conhecimento e das condições cognitivas que comporta", de aprendizagem dos fenômenos visuais, da expressão verbal daquilo que se produz visualmente, sendo imprescindível "saber o que se produz visualmente no âmbito intrínseco da imagem" (ibid., p. 17), enfim, educar o olhar (ibid., p. 89). Essa possibilidade de "alfabetização visual" foi observada durante a pesquisa empírica em relação aos trabalhos desenvolvidos pelo Projeto Olhar Complexo, de Bruno Itan, no Complexo do Alemão. Um aprendizado que se estrutura a partir do desenvolvimento da sensibilidade e dos conhecimentos correspondentes que permitem "saber como pensam as imagens, como contêm e indicam ideias e emoções" (ibid., p. 17), assim seria possível acessar a potência da percepção, pois 
as "imagens são capazes de conduzir os processos reflexivos: esclarecendo ideias ou propondo-as" (ibid.).

As técnicas de interatividade e de interface que tornam possível a associação entre corpo e imagem, como nas propostas das televisões híbridas, dos dispositivos touch, dos dispositivos de realidade virtual, dos museus digitais ou das instalações interativas de realidade virtual, fariam parte das inúmeras possibilidades do olhar estético do afeto, da alteração, modulagem e calibragem perceptiva do espectador, da transição do status de receptor passivo a ativo, do processo de desterritorializar para reterritorializar. Seria uma espécie de canalização dos dispositivos de imaginação do espectador que permitiria o trânsito da contemplação à ação, em uma espécie de conjugação entre a imagem e a imaginação, antes separadas (Català Domènech, 2011, p. 94), dependendo, necessariamente, do movimento. Esta é a possibilidade de se ter a experiência direta, referida por Merleau-Ponty (1999, p. 141), de experimentar uma espécie de descontinuidade entre a representação e o real, construindo um regime de visibilidade muito próximo da concepção merleaupontyana de percepção. Este é o canal para reterritorializar a cidade.

São reflexões que nos provocam a repensar a tela na relação entre fotógrafo, fotografado, receptor e a própria imagem. Professor Mauro Carbone (Carbone, 2019) traz o conceito de archi-écran para refletir sobre a tela para além da representação visual, como condição da visão e da imaginação no atual regime de visualidade e visibilidade, do jogo do "esconder e mostrar", daquela transição do contemplativo para o ativo descrito por Arendt (2007), ou seja, um movimento de deixar o quadro e sair da moldura, de ver através da janela. Reflexões que se coadunam com aquelas propostas por Català Domènech; afinal, "agora, a realidade virtual nos oferece a possibilidade de atravessar essa janela e ter acesso à realidade do outro lado: a distância entre quadro e espectador na qual se baseava o ilusionismo perspectivista se anulou e é possível penetrar nas imagens" (Català Domènech, 2011, p. 93). Este é o realismo imersivo techno, a interatividade, a interface, a realidade aumentada (ibid., pp. 99 ss); uma nova forma de impressão da realidade, a própria onipresença das telas na atualidade, ancorando o desejo - antropofágico - de ver e ver-se. São telas que projetam modelos espetaculares de representações com a pretensão de reproduzir da forma mais perfeita a realidade, não restrita à construção de um outro real. Contudo, as janelas dos novos dispositivos podem nos liberar ou nos aprisionar, seja no modo de ver, seja no modo que produzimos aquilo que desejamos ver, que seja visto e de nos vermos projetados. São interferências na dimensão afetiva, provocando uma reflexão sobre o afeto em uma sociedade que se divide em um duplo vivido, entre o físico e o virtual; em uma cidade dividida entre espaços de inclusão e outros comunicados como violentos.

Català Domènech (2011, pp. 95-96) defende que a interface é a novidade autêntica na imagem contemporânea, uma nova forma de construção de realidade, uma imagem que não tem limites precisos, inscrita no interior de molduras, cenários ou telas, que transborda a tela do computador e se potencializa em seus acessórios periféricos, passando a fazer parte dessa nova forma de imagem em uma espécie de visualidade operacional: "o corpo desse usuário-gestor e a representação formam uma unidade operacional que age conjuntamente" 
Figura 4-A moldura do olhar

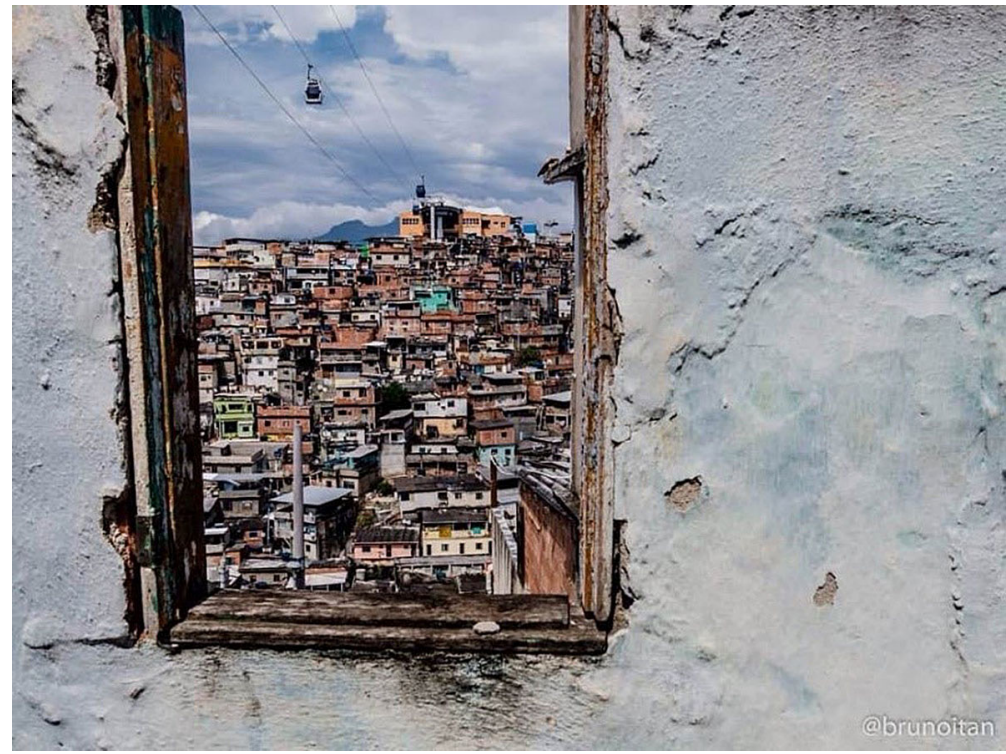

Foto de Bruno Itan.

Fonte da imagem: https://www.instagram.com/p/BmObcUPAd20/

(ibid., p. 96). São essas as janelas que se abrem para um novo regime visual e outra imagem de sociedade. A interface traz a possibilidade da experiência tátil aproximada do conceito merleaupontyano (Merleau-Ponty, 1999, pp. 293-294), associada a uma experiência visual potencializada, transferindo-nos ao espaço do outro para experimentar sua vida, incorporada virtualmente. Segundo Merleau-Ponty, "toda a sensação é espacial porque, enquanto contato primordial com o ser, enquanto retomada, pelo sujeito que sente, de uma forma de existência indicada pelo sensível, enquanto coexistência entre aquele que sente e o sensível, ela própria é constitutiva de um meio de experiência, quer dizer, de um espaço" (ibid., p. 298), o que traduz a essência da reterritorialização. Uma experiência disparada pela câmera fotográfica, que, para Lévy (2007, p. 97), seria uma ferramenta da memória longa, uma máquina de perceber que funciona no nível direto e estende o alcance para transformar a natureza de nossas percepções. Quando aliada às redes de computadores, em sua dimensão indireta, a câmera fotográfica seria responsável por modificar nossa relação com o mundo, com o espaço e com o tempo em um nível que não é possível dizer se ela transforma o mundo humano ou nossa maneira de percebê-lo (ibid.).

Carne y Arena, um projeto de realidade virtual escrito e dirigido por Alejandro González Iñarritu, em 2017, é um exemplo dessa experiência estética que pode promover a 
reterritorialização. Uma experiência que oferece a potência do espanto, que é a essência da fotografia, segundo Barthes (2015, p. 71), e do afeto surpresa, como um resetting affect, tal como preconizado por Tomkins (1962 e 1963), capaz de reiniciar nossa programação perceptiva a partir da incorporação da experiência do outro. É a demonstração da possibilidade das projeções mentais, da reconfiguração da relação tempo-espaço e do seu reflexo no canal perceptivo. É a possibilidade de o espectador ter a experiência de um imigrante, sentindo na pele a luta para sobreviver à travessia México-Estados Unidos. Uma experiência estética que usa a tecnologia de realidade virtual na qual o espectador vê e sente aquilo que geralmente assiste em forma de notícia, distanciado daquela experiência de um outro diferente e afastado. A realidade aumentada pode promover a transição da empatia à simpatia quando o espectador experimenta o sofrimento desse outro. Uma experiência que efetivamente coloca o espectador no lugar do outro, fazendo-o sentir o "lugar" desse outro, ao mesmo tempo que desterritorializa sua imagem e processa a reterritorialização do espectador através de uma imagem projetada, permitindo que se estenda essa experiência à reterritorialização dos espaços e das relações afetas ao espectador. Você é o ponto de referência dessa experiência, como é de qualquer fotografia, conforme preceituava Barthes (2015, p. 72), "e é nisso que ela me induz a me espantar, dirigindo-me a pergunta fundamental: por que será que vivo aqui e agora?" (ibid., p. 72). Você tem a possibilidade de olhar diferente a partir dessa experiência, de se modificar a partir daquilo que sentiu e viu porque foi afetado pela experiência; isto porque a fotografia, explica Barthes, coloca uma imediata presença no mundo (ibid., p. 72), uma "presença política ('participar dos acontecimentos contemporâneos pela imagem') e também metafísica" (ibid.); mais ainda, é a experiência de realidade virtual que demonstra visceralmente o poder da fotografia, da imagem, do imaginário, da emoção e do afeto.

Projetos como Carne y Arena oferecem a possibilidade de reterritorialização, além da deflagração de movimentos catárticos a partir de uma série de relações psicológico-imaginativas (Català Domènech, 2011, pp. 97-98), na qual é "produzida uma relação imaginária entre um espectador passivo e uma representação ativa destinada a transformar a alma desse espectador" (ibid., p. 98). Seria uma espécie de inversão das relações entre representação e espectador materializada pela interface (ibid.), concentradas em único lado: "o usuário-gestor não só experimenta transformações mentais como age fisicamente por meio de seus gestos, os quais influem na transformação da imagem, que assim recebe parte das consequências da atividade mental" (ibid.). Desta maneira, defende Català Domènech, "a forma da imagem é em parte um eco da imaginação desse usuário-espectador, da mesma maneira que sua imaginação é o eco das atividades da representação" (ibid.), em um processo de identificação e distanciamento (ibid.); como uma espécie de análise reflexiva preconizada por Merleau-Ponty (1999, p. 295). É a possibilidade da experiência de um mundo como totalidade aberta, mas cuja síntese não pode ser acabada (ibid., p. 296); afinal, "existem talvez, seja na experiência sensorial, seja em cada consciência, 'fantasmas' que nenhuma racionalidade pode reduzir" (ibid., p. 297). 
Nesse novo regime imagético, o machinima apresenta-se como possibilidade para esse processo de reterritorialização. 0 machinima é uma técnica de produção que utiliza sequências de vídeos ou fotografias capturadas no interior dos espaços virtuais em tempo real, geralmente produzidas através do software interno ou externo de um videogame, que é a mediação narrativa dessa interação. 0 jogador - machinimamaker transforma-se no realizador do filme de vídeos ou fotografias e difunde suas produções nas próprias redes ou em sites de jogos, em que geralmente são usuários/jogadores que demonstram o redimensionamento da imagem, do papel do próprio espectador. 0 machinima representa o apagamento das diferenças entre espectador e criador. É esta a linguagem de Isabelle Arvers $^{3}$ em suas performances, instalações e produções, estabelecendo uma nova forma de experimentar o real, demonstrando que essa prática é também uma forma de construção de memória. ${ }^{4} 0$ machinima apresenta-se como alternativa para reencontrar aquele encantamento puro das imagens, referido por Rancière (2012): "a identidade mítica entre a identidade do 'isso' (ça) e a alteridade do 'foi' (a-eté), entre o prazer da presença pura e a mordida do Outro absoluto" ( pp. 31-32). É uma experiência de imersão e a possibilidade de outras intensidades de afeto, ou seja, outra experiência perceptiva proporcionada pela projeção das imagens em outra dimensão tempo-espaço. Arvers busca a imersão nos espaços - virtuais e físicos - e a possibilidade de explorá-los sob outra perspectiva, por intermédio da sua câmera virtual. A gameartist cria novos espaços abstratos que se movimentam diante do espectador, localizando-o em uma espécie de janela "tempo-espaço", como se estivesse na janela de um veículo em movimento. Uma forma de ver, assistir e olhar as paisagens em movimento através dessa janela/tela, em uma nova experiência interativa e visual de interface, tal como referida por Carbone (2019). Uma experiência horizontalizada, em uma espécie de escrita visual, como descreve Català Domènech (2011, p. 97), "fundamentada no corpo e na imaginação combinados". Arvers acredita criar, nesses espaços abstratos, uma outra possibilidade de ação e de sentir, como nos machinimas Mer Bleu Rose, Mer Violette, Mer Superpink, ${ }^{5}$ nos quais "você sente fisicamente as cores se movimentando em torno de nós; um mar que não faz molhar, que não é perigoso". 6

Em que medida esse tipo de imersão poderia retroalimentar padrões de interpendência é uma reflexão que se faz necessária neste trabalho, pois a amplitude de uma calibragem perceptiva em relação à segurança impressa por uma aparente proteção neste tipo de interação pode despertar um distanciamento e um isolamento do usuário, que passa a viver uma espécie de encapsulamento, ainda que essas imagens-interface possam ser lidas como "representações puramente cognitivas" (ibid., p. 97), indicando uma "materialização do olhar", ou seja, a interface manifestaria um momento de complexidade não só da imagem, mas também do olhar, conforme observa Català Domènech (ibid.), especialmente nas experiências de realidade virtual. Experiências estéticas como o machinima oferecem novas formas de perceber, afetar, afetar-se e agir; afinal, de acordo com o autor, a interface não é apenas o espaço do visível, restrito à superfície de demonstração, mas todo um espaço virtual, "que em parte é projeção do computador no sentido do usuário-gestor e em parte projeção 
do usuário-gestor no sentido do computador" (ibid.), na projeção de imagens equivalentes e da possibilidade da visualização das transformações dessas imagens a partir da interação corpo-dispositivo, formando uma outra imagem a partir de um outro corpus. É uma forma de potencializar a experiência de imersão no conteúdo imaginado daquilo que vemos nos registros fotográficos, aproximando-nos do contexto no qual foi produzido, entendido por Kossoy (2016, p. 132) como um "exercício mental de reconstituição quase que intuitivo". Um formato também observado no machinima Zimako, de la jungle de Calais, ${ }^{7}$ um exemplo de reterritorialização a partir da justaposição das imagens do real com a criação virtual no ciberespaço. Um machinima que faz refletir sobre os campos de refugiados como espaços de exclusão. É uma forma de fotorrealismo e dos questionamentos que esta estética suscita. Uma nova maneira de construir a realidade de espaços invisibilizados ou comunicados em narrativas diversas daquelas que ocupam e usurpam aqueles espaços. Machinima é uma nova forma de perceber esses espaços, a comunicação inside/outside e, principalmente, o outro. Machinima é a chance de criar um espaço comum de comunicação mediado pelo afeto, um medium alternativo de afetar e afetar-se a partir de um redimensionamento dos espaços e da participação do usuário/espectador/agente. É a reconfiguração da percepção e do imaginário, conjugando dois espaços e múltiplas realidades produzidas pelo usuário/ espectador/agente.

Talvez seja a realidade aumentada, a estética mais fácil e menos simples de se adequar ao processo de desterritorialização-reterritorialização, não pela fluidez das imagens que é a tônica da visualidade contemporânea, mas pela possibilidade da substituição do real pelo virtual de uma forma mais radicalizada. Uma estética que extrapolaria a possibilidade de ser uma nova relação espacial ao transformar-se na fragmentação da própria "vida real". Essa é a estética de um tempo que é particularizado nessas imagens fractais (Català Domènech, 2011, pp. 104 ss), o tempo das imagens técnicas, de uma nova forma de fotografia ou de localização da relação espaço-tempo, pois se é verdade que a fotografia incorpora a própria realidade às imagens, como ressalta Català Domènech, é inconteste que o tempo faz parte dessa incorporação, da própria projeção desse real a uma nova concepção de movimento, perceptível a partir do estranhamento do real e de sua representação, fazendo-nos refletir sobre o próprio sentido de "cópia", comumente associada ao processo de virtualização. Lévy (2007, p. 65) lembra-nos que uma das dimensões complementares do macropsiquismo é a dimensão energética, responsável por especificar a força dos afetos ligados às imagens, relacionada às principais operações do megapsiquismo, aquelas que criam ou modificam representações e imagens, além de modificarem, deslocarem, aumentarem ou diminuírem a força dos afetos ligados a esta ou àquela representação em circulação, como também criam, transformam ou mantêm os afetos sociais (ibid., pp. 65-66). É uma nova experiência perceptiva que se abre por intermédio da imagem fotográfica afetada tecnologicamente, uma imagem que se desterritorializa e, quando projetada, pode promover a reterritorialização. Esse processo permite pensar o Rio de Janeiro por outra perspectiva, a partir de outros atores e tecnologias. Uma cidade que passa a se reimaginar a partir da sua reterritorialização, através do olhar da favela. 


\section{Conclusão}

Buscamos com este trabalho de pesquisa pensar uma cidade pós-neoliberal, a partir do que chamamos de reterritorialização; uma proposta para reprogramar o padrão comunicativo das relações da cidade do Rio de Janeiro por intermédio da experiência estética, reunindo percepção e afeto. Transformar a maneira como se percebe a realidade é a função do olhar estético do afeto. Uma técnica que busca construir novas relações, a partir de novas experiências perceptivas, e promover novas formas de calibragem e modulagem de percepção, a partir da experiência fotográfica, ancorada na concepção merleaupontyana de que nossa percepção é influenciada pela perspectiva. A fotografia seria o medium dessa técnica que pretende "relocalizar" o sujeito diante do outro, do outro espaço, em uma cidade marcada por uma estética segregacionista. É a reprogramação perceptiva a partir de outra perspectiva: a favela. A fotografia é capaz de inúmeras configurações comunicativas entre fotógrafo, fotografado e imagem fotográfica. Se a experiência fotográfica é capaz de reconfigurar a imagem da cidade, o olhar estético do afeto vai além, para promover a reterritorialização de suas relações, imprimindo um novo olhar, uma nova forma de perceber, imaginar, comunicar e atuar. $\mathrm{O}$ afeto, inserto no próprio ato de perceber, atua radicalmente transformando o olhar e fazendo agir. Deixo de ver apenas a imagem para me comprometer com aquilo que olho. Esse comprometimento altera não só a percepção do sujeito, mas gera outros padrões de comunicação despertados pelos afetos e é capaz de múltiplos contágios afetivos.

Figura 5 - Os laços de afeto da favela

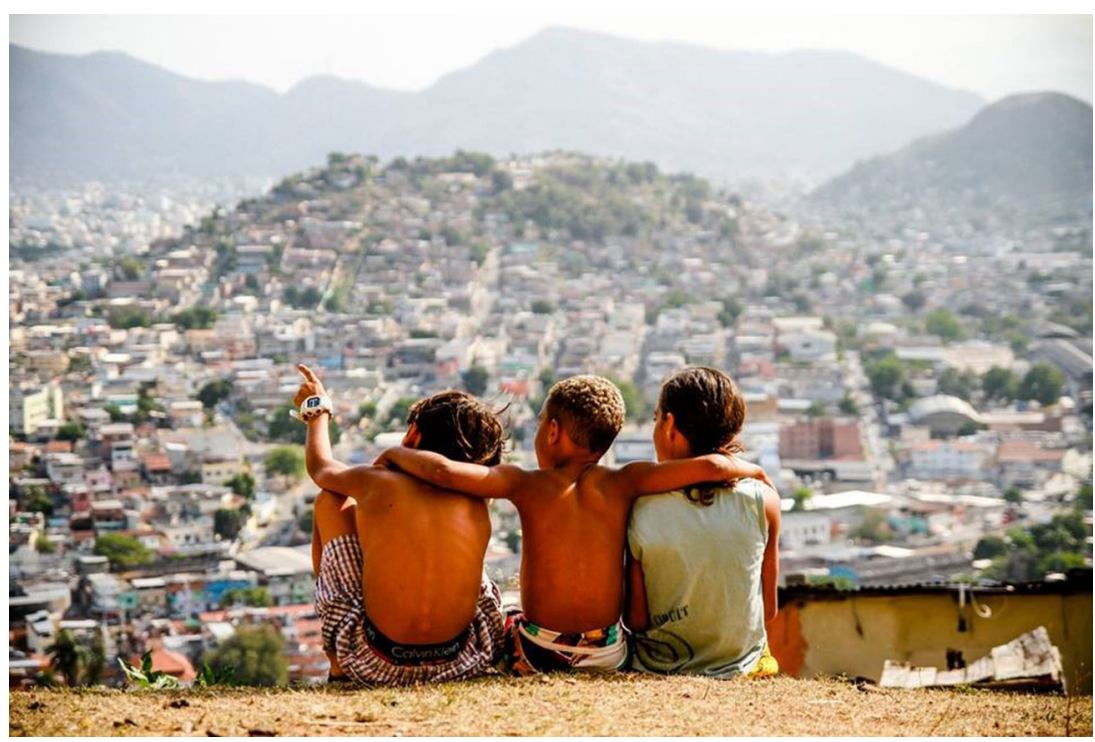

Foto de Bruno Itan

Fonte da imagem: https://fhox.com.br/albuns/exposicao-olhar-complexo-bruno-itan/ 
O olhar estético do afeto permite o processo de desterritorialização e reterritorialização a partir da virtualização das imagens e sua projeção. Como a intenção é a reterritorialização da cidade e mudança do seu padrão comunicativo, propomos a virtualização das imagens produzidas pelos moradores das favelas do Rio de Janeiro, que revelaria o olhar do invisível, dando, como exemplo, o trabaIho produzido pelo Projeto Olhar Complexo, fundado e dirigido pelo fotógrafo Bruno Itan, morador do Complexo do Alemão. Projetos acoplados às tecnologias de virtualização, como é a experiência da realidade aumentada, podem processar a reterritorialização a partir de outra perspectiva: o olhar do sujeito oprimido, o morador da favela. Este é o caso de Carne y Arena, criado por Alejandro González Iñarritu, uma experiência estética que promove a desterritorialização e a reterritorialização no mesmo ato, em uma abertura simultânea de tempo e espaço, vivenciada em outra dimensão, fazendo com que o sentimento se fixe em duplo, entre real e virtual, tal como a fotografia da pessoa que morreu ou de uma imagem que você já viveu: você revive, vive, experimenta, sente e se afeta novamente, em um único tempo, uma mesma dimensão, e com a possibilidade de modificar sua percepção e seus afetos, reprogramando sua maneira de olhar para o outro, para o outro espaço, e reconstruir os espaços e as relações a partir do olhar desse outro, como é possível experimentar com o machinima Zimako, de la jungle de Calais, criado por Arvers.

São essas experiências que nos ajudam a pensar o que seria a reterritorialização a partir de outras perspectivas, responsável por reconfigurar as imagens e as relações no espaço urbano. A reterritorialização é a cidade reimaginada, é a possibilidade de o Rio de Janeiro se reinventar através do olhar da favela.

\section{[I] https://orcid.org/0000-0002-3860-8500}

Universidade Federal do Rio de Janeiro, Faculdade Nacional de Direito, Programa de Pós-Graduação em Direito Federal. Rio de Janeiro, RJ/Brasil.

liatorraca@adv.oabrj.org.br 


\section{Notas}

(1) Vale registrar que Guattari (1992), em seu livro Caosmose: um novo paradigma estético,se reporta aos pensamentos de Lévy ao falar sobre desterritorialização; das possibilidades dos territórios existenciais de transmudarem, germinarem e se transfigurarem; da imagem transportada por devires; sobre os afetos estéticos, sempre a partir de sua perspectiva de "fazer transitar as ciências humanas e as ciências sociais de paradigmas cientificistas para paradigmas ético-estéticos" (ibid., p. 21). É sob essa perspectiva que Guattari e Deleuze pensaram outro sentido para a territorialidade, não apenas como um conceito associado à geografia e ao controle espacial, como é possível observar na série Mil Platôs (Deleuze e Guattari, 1995; 1997), mesmo porque o conceito de território sempre serviu à política como parte da linguagem de - disputa - poder. Vale ressaltar que é Lefebvre quem primeiro buscou oxigenar o conceito de territorialidade, ao pensar sobre espaço associado à percepção na produção social do espaço. Sobre o conceito de territorialidade, espaço e direito à cidade, ver Lefebvre (1974 e 2001).

(2) Em setembro de 2017, antes do evento Rock in Rio, a Riotur, instituição responsável pela promoção turística da cidade do Rio de Janeiro, distribuiu mapas oficiais subtraindo algumas favelas do Rio de Janeiro, como, por exemplo, a favela da Rocinha. Ver Torraca (2019, p. 15).

(3) Ver páginas: <http://www.isabellearvers.com/>; <http://www.isabellearvers.com/wp-content/ uploads/atelier-machinima>; <https://www.slideshare.net/ICASL3/les-machinimas>; <http:// www.isabellearvers.com/2018/05/residence-videoformes-2017-2018/\#haut>; <http://www. isabellearvers.com/2019/01/residency-in-platohedro-medellin-august-18/>; acesso em: 5 mar 2019.

(4) Carte Postale Voyage é um dos projetos de Arvers como construção de memória, mas também demonstra a potencialidade de reterritorialização através das emoções, captadas nos espaços projetados no machinima, que inclui imagens fotográficas da favela, em uma montagem entre o real e o virtual, impressas em um vídeo cartão-postal. Vídeo disponível em: <https://youtu.be/ Jh94K9WIo9U>; acesso em 5 mar 2019. Sobre cartão-postal e a "civilização da imagem", sobre a possibilidade do conhecimento visual do mundo, da reprodução e da acessibilidade das imagens mentais do mundo real, tanto as individuais quanto as coletivas, e da liberação do imaginário ficcional, ver Kossoy (2016, pp. 61ss).

(5) Machinima disponível em: <https://www.gamescenes.org/2019/01/game-art-isabelle-arvers-lamer-2019.html>; acesso em: 5 mar 2019.

(6) Informações disponíveis em: <https://youtu.be/HjbLPWoiAFO|>; acesso em: 5 mar 2019.

(7) Machinima disponível em: <https://www.youtube.com/watch?v=elqX2iclEts>; acesso em: 5 mar 2019. 


\section{Referências}

ARENDT, H. (2007). A condição humana. Rio de Janeiro, Forense Universitária.

ARISTÓTELES (2018). Da alma. São Paulo, Edipro.

AZOULAY, A. (2008). The civil contract of photography. Nova York, Zone Books.

BADIOU, A. (2018). A metafísica da felicidade real. São Paulo, Martins Fontes.

BARTHES, R. (2015). A câmara clara: nota sobre a fotografia. Rio de Janeiro, Nova Fronteira.

BENJAMIN (2013). Escritos sobre mito e linguagem (1915-1921). São Paulo, Editora 34.

(2017). Estética e sociologia da arte. Belo Horizonte, Autêntica.

BERLEANT, A. (2000). The aesthetic field: a phenomenology of aesthetic experience. Christchurch, Cybereditions.

BOGRE, M. (2012). Photography as activism: images for social change. Oxford, Focal Press.

CARBONE, M. (2019). Ver segundo o quadro, ver segundo as telas. Caxias do Sul, Editora da Universidade de Caxias do Sul.

CATALÀ DOMÈNECH, J. (2005). La imagen compleja: la fenomenologia de las imágenes em la era de la cultura visual. Barcelona, Universitat Autònoma de Barcelona.

(2011). A forma do real. São Paulo, Summus.

CHARAUdeAU, P. (2006). Discurso das mídias. São Paulo, Contexto.

CORTINA, A. (2017). Aporofobia, el rechazo al pobre. Barcelona, Espasa Libros.

COSTA, L. (2010). Imagem dialética e imagem crítica: fotografia e percepção na metrópole moderna e contemporânea. Tese de Doutorado. São Paulo, Universidade de São Paulo.

DEBORD, G. (1997). A sociedade do espetáculo. Rio de Janeiro, Contraponto.

DELEUZE, G. (1998). Spinoza: pratical philosophy. San Francisco, City Light Books.

DELEUZE, G.; GUATTARI, F. (1995). Mil Platôs - capitalismo e esquizofrenia, v. 1, 2, 3. Rio de Janeiro, Editora 34.

(1997). Mil Platôs - capitalismo e esquizofrenia, v. 4. São Paulo, Editora 34.

DIDI-HUBERMAN, G. (2010). O que vemos, o que nos olha. São Paulo, Editora 34.

(2015). Diante da Imagem. São Paulo, Editora 34.

(2016). Que emoção! Que emoção? São Paulo, Editora 34.

DUARTE, C. (2019). “A 'reinvenção' da cidade a partir dos espaços populares”. In: ALVARES, L.; BARBOSA, J. (orgs.). Espaços públicos urbanos: das políticas planejadas à política cotidiana. Rio de Janeiro, Letra Capital.

GUATTARI, F. (1992). Caosmose: um novo paradigma estético. São Paulo, Editora 34.

KOSSOY, B. (2016). Realidades e ficções na trama fotográfica. São Paulo, Ateliê Editorial. 
LEFEBVRE, H. (1974). La production de l'espace. Paris, Edition Anthropos. (2001). O direito à cidade. São Paulo, Centauro.

LÉVY, P. (2007). O que é o virtual? São Paulo, Editora 34.

LOPES, C.; PIMENTEL, F. (2011). "A metodologia da pesquisa no Direito e Maurice Merleau-Ponty". In: ROCHA, S. et al. Metodologia de pesquisa em Direito e a filosofia. São Paulo, Saraiva.

MARTINS, J. (2017). Sociologia da fotografia e da imagem. São Paulo, Contexto.

MASSUMI, B. (s/d). The Autonomy of Affect. Disponível em: http://www.brianmassumi.com/textes/ Autonomy\%20of\%20Affect.PDF. Acesso em: 11 set 2017.

MERLEAU-PONTY, M. (1999). Fenomenologia da percepção. São Paulo, Martins Fontes.

MOHOLY-NAGY, L. (1947). The new vision and abstract of an artist. Disponível em: https://monoskop. org/images/a/af/Moholy-Nagy_Laszlo_The_New_Vision_and_Abstract_of_an_Artist.pdf. Acesso em: 5 dez 2017.

(1995). In focus. László Moholy-Nagy: photographs from the J. Paul Getty Museum. Los Angeles, The J. Paul Getty Museum.

RANCIÈRE, J. (2012). O destino das imagens. Rio de Janeiro, Contraponto. (2018). A partilha do sensível: estética e política. São Paulo, Editora 34.

SONTAG, S. (2004). Sobre fotografia. São Paulo, Companhia das Letras.

SPINOZA, B. (2017). Ética. Belo Horizonte, Autêntica.

TOMKINS, S. (1962). Affect imagery consciousness - Volume I-The positive affects. Nova York, Springer. (1963). Affect imagery consciousness - Volume II - The negative affects. Nova York, Springer.

TORRACA, L. (2019). O espetáculo da violência no Rio de Janeiro e o olhar estético do afeto. Tese de Doutorado. Rio de Janeiro, Universidade Federal do Rio de Janeiro.

WATZLAWICK, P. (1991). A realidade é real? Lisboa, Relógio d’Água.

Texto recebido em $9 / \mathrm{jun} / 2020$

Texto aprovado em $31 / \mathrm{jul} / 2020$ 